\title{
Changes in chemical properties of an Ultisol as affected by palm oil mill effluent application
}

\begin{abstract}
An experiment was conducted to determine the effects of palm oil mill effluent (POME) application on soil chemical properties. The POME was incorporated into the top 0-30 cm of Batang Merbau soil, an Ultisol. POME was applied at 0, 5, 10, 20, and $40 \mathrm{t}$ ha-1, both in the presence and absence of $2 \mathrm{t}$ ground magnesian limestone (GML). A succeeding crops of maize and groundnut were planted. The results of the experiment showed that POME application up to the rate of $40 \mathrm{t}$ ha- 1 did not significantly change the topsoil $\mathrm{pH}$ and exchangeable calcium $(\mathrm{Ca})$, magnesium $(\mathrm{Mg})$, and aluminum (Al). The addition of POME improved the soil fertility, which resulted in an increase of maize yield. The $\mathrm{Ca}$ and $\mathrm{Mg}$ from the POME accumulated in the topsoil, being held by the negative charge present on the exchange complex. The beneficial effects of POME and/or GML application lasted for about 3 years. The study indicated that application of POME together with GML is a good agronomic option to alleviate soil acidity in Ultisol for maize production.
\end{abstract}

Keyword: Palm oil mill effluent; Chemical property; Soil acidity; Ultisol 